\title{
Influence of Pasteurization on Total Phenols Content and Antioxidant Capacity of Prunus persica L. Juices
}

\author{
Vasile LASLO $^{1}$, Alin C. TEUSDEA ${ }^{1}$, Sonia A. SOCACI ${ }^{2}$, \\ Daniel MIERLITA ${ }^{1}$, Simona I. VICAS ${ }^{1 *}$ \\ ${ }^{1}$ University of Oradea, Faculty of Environmental Protection, 26 Gen. Magheru St., 410048 Oradea, \\ Romania; vasilelaslo@yahoo.com; ateusdea@gmail.com; dadi.mierlita@yahoo.com; svicas@uoradea.ro (*correspondingauthor) \\ ${ }^{2}$ University of Agricultural Sciences and Veterinary Medicine, Faculty of Food Science and Technology, 3-5 Manastur St., 400372 Cluj-Napoca, \\ Romania; sonia.socaci@usamvcluj.ro
}

\begin{abstract}
Peach and nectarine (Prunus persica) production has an important place in the world, being the most important fruit after apple crops in the European Union. Because the fruits are perishable, it is desirable to valorize them as juice. Seven peaches and three nectarines cultivars grown in the N-W part of Romania were investigated for quality parameters, volatile profile, total phenols content and antioxidant capacity. The volatile composition of peach and nectarine cultivars was determined via the ITEX/GC-MS technique, the main volatile compounds belonging to alcohols and aldehydes. Another objective was to obtain the pasteurised juices from these fruits and to investigate the best time of pasteurisation in order to identify the most valuable cultivar from the perspective of total phenols content and its antioxidant capacity. For a better interpretation of results and a proper discrimination between cultivars, according to the total phenols content and antioxidant capacity, the multivariate analysis, Principal Component Analysis (PCA) and Hierarchical Cluster Analysis (HCA) were applied. The peach cultivars showed the highest content in total phenols compared with nectarine. From peach cultivars, the highest concentration was recorded in 'Southland' ( $\left.47.49 \pm 0.14 \mathrm{mg} \mathrm{GAE} 100 \mathrm{~g} \mathrm{~g}^{-1} \mathrm{FW}\right)$ and from nectarine cultivars in 'Romamer' $(16.28 \pm 0.83 \mathrm{mg} \mathrm{GAE}$ $100 \mathrm{~g} \mathrm{gW}^{-1} \mathrm{FW}$. The highest antioxidant capacities were recorded in 'Southland' peach in the case of both methods (DPPH and FRAP). The results showed that 'Southland' peach and 'Romamer' nectarine pasteurised juices are the best from the point of view of total phenolic compounds content with high antioxidant capacity.
\end{abstract}

Keywords: DPPH, FRAP, nectarine, peach, total phenolic compounds, volatile profile

\section{Introduction}

Peach (Prunus persica L.) production has an important place in the world, being the most important fruit after apple crops in the European Union. Romania had a production of 19130.00 tons in 2013 and a cultivated area of around 2.036 ha (FAOSTAT, 2016). Fruit and natural fruit juice represent a very important component of a healthy diet. Numerous studies have highlighted their antioxidant potential and beneficial effects on human organism (Tavarini et al., 2008; Hegedus et al., 2010; Abidi, et al., 2011; Legua et al., 2011; Oliveira et al., 2012; Lutz et al., 2015; Noratto et al., 2015). Diet supplemented with peaches have boosted lipid metabolism and have increased the antioxidant potential of blood plasma (Leontowicz et al., 2002). The antioxidant capacity of fresh fruit and natural fruit juices is determined by the cultivar, the micro- climate conditions, the soil land its fertility, by applied agrotechnics, time of harvest, applied processing technology (Hegedus et al., 2010; Legua et al., 2011; Oliveira et al., 2012; Martínez-Las Heras et al., 2016). In peaches and nectarines, the main compounds that determine their antioxidant capacity are polyphenols, carotenoids and vitamin C (Gil et al., 2002). Tomás-Barberán et al. (2001) quantified the phenolic compounds of twenty-five peach, nectarine, and plum cultivars using HPLC-DAD-ESIMS, and the result shown that the fruits include a wide range of compounds, such as hydroxycinnamates, condensed tannins, hydrolyzable tannins, flavonols and anthocyanin.

There is a growing interest in consumer markets for natural fruit juices with numerous nutrients and phytochemicals such as vitamins and phenols (European Fruit Juice Association, 2016, Liquid Fruit, Market Report). Processing methods, can affect their content in these biologically active compounds. During thermal treatment, a series of unwanted processes (loss of antioxidant 
554

compounds, non-enzymatic roasting reactions, 5-HMF formation) can occur (Kowalski et al., 2013). The release of phenolic compounds from fruit matrix can also occur, and thus the above mentioned compounds may become more accessible (Lemmens et al., 2009; Lemmens et al., 2010).

The aim of this investigation was to determine some parameters related to fruit quality, total phenols content, antioxidant capacity, as well as the volatile compounds of three nectarines and seven peach cultivars grown in the NW part of Romania. In order to obtain the beverages rich in phenolic compounds, the total phenols content and antioxidant capacity were evaluated at different time of pasteurisation (15, 20 and 25 minutes). For a better interpretation of results and a proper discrimination between cultivars, according to the total phenols content and antioxidant capacity, multivariate analysis, namely the Principal Component Analysis (PCA), and Hierarchical Cluster Analysis (HCA) were performed.

\section{Materials and Methods}

\section{Locality description and collection of samples}

Fruits were harvested from a Romanian orchard situated at $183 \mathrm{~m}$ above sea level, with southern exposure, the mean annual temperature being $8.75{ }^{\circ} \mathrm{C}$ and $491.7 \mathrm{~mm} / \mathrm{m}^{2} /$ year precipitation. Soil type was classified as argilo alluvial. The climatic and geographic area of the land $\left(47^{\circ} 9^{\prime} 55^{\prime \prime}\right.$ North, $21^{\circ}$ $56^{\prime} 37^{\prime \prime}$ West) offers good conditions for the cultivation of thermophilic fruit tree species (apricot, peach, almond). The experiments were carried out using seven peach cultivars ('Amalia', 'Antonia', 'Cardinal', 'Collins', 'Jerseyland', 'Redhaven' and 'Southland') and three nectarine cultivars ('Ark 125 , 'Crimsongold' and 'Romamer'), some of them with white or yellow flesh.

\section{Fruit quality indices}

Fruit weight $(\mathrm{g})$ and diameter $(\mathrm{mm})$ of 20 randomly selected fruits of each cultivar was measured. Soluble solid content (SSC, ${ }^{\circ}$ Brix) was determined for the juice of each cultivar using a Digital Handheld Refractometer (DR201-95, A.KRÜSS Optronic GmbH, Germany). The $\mathrm{pH}$ of diluted fruit pulp with distilled water $(1: 10, \mathrm{w} / \mathrm{v})$ was measured using a $\mathrm{pH}$-meter (WTW GmbH inoLab ${ }^{\circ} \mathrm{pH}$ 7200). Titrable acidity (TA) was determined by titrating $10 \mathrm{ml}$ of diluted fruit-juice $(1: 10, w / v)$ with $0.1 \mathrm{M} \mathrm{NaOH}$. Three titration analyses per cultivar were performed, and the data were expressed in $\mathrm{g}$ malic acid $\bullet 100 \mathrm{~g}^{-1}$ fresh weight $(\mathrm{FW})$. The ripening index (calculated as the ratio between SSC and TA) was used as an indicator of taste quality (Hegedus et al., 2010).

\section{Measurement of total phenols content and determination of antioxidant capacity offruits}

To determine the total phenols content from fruits, ten grams of flesh from each replicate were homogenized with 100 $\mathrm{ml}$ distilled water, and the centrifuged at $15000 \mathrm{rpm}$ for 15 minutes. After centrifugation, the supernatants were used for the measurement of total phenols by the Folin-Ciocalteu method (Singleton et al., 1999). The supernatant of fruit (100 $\mu \mathrm{l})$ was mixed with $1700 \mu \mathrm{l}$ distilled water, $200 \mu \mathrm{l}$ FolinCiocalteu reagent (dilution $1: 10, \mathrm{v} / \mathrm{v}$ ) and $1000 \mu \mathrm{l}$ of $15 \%$ $\mathrm{Na}_{2} \mathrm{CO}_{3}$ solution. The mixture was incubated at room temperature, in the dark, for 2 hours. Also, a blank containing distilled water was prepared. The absorbance was measured at $765 \mathrm{~nm}$ using a spectrophotometer (Shimadzu $1240 \mathrm{mini}$ UVVis). The results were expressed in mg gallic acid equivalents (GAE) $\bullet 100 \mathrm{~g}^{-1} \mathrm{FW}$. All total phenols values were corrected by subtracting the ascorbic acid content.

The antioxidant capacities of peach and nectarines extracts were studied in two antioxidant assays: scavenging DPPH radical and ferric ion reducing antioxidant power (FRAP) (Benzie and Strain, 1996). The DPPH radical-scavenging activity was determined using the method proposed by Singleton et al. (1999). Briefly, an aliquot of $100 \mu \mathrm{l}$ sample was mixed with $1.4 \mathrm{~mL}$ of DPPH solution $(80 \mu \mathrm{M})$ and $1 \mathrm{ml}$ ethanol. The homogenate was shaken vigorously and the decrease in the absorbance of the resulting solution was monitored at $515 \mathrm{~nm}$ for $5 \mathrm{~min}$ on a spectrophotometer (Shimadzu 1240 mini UV-Vis). The percentage of scavenging effect of different extracts against DPPH radical, was calculated using the Eq.1 (1): (Eq.1)

DPPH scavenging effect $(\%)=\left[\left(\mathrm{A}_{0}-\mathrm{A}_{\mathrm{S}}\right) \times 100\right] / \mathrm{A}_{0}$ where, $\mathrm{A}_{0}$ is absorbance of the blank, and $\mathrm{A}_{\mathrm{s}}$ is absorbance of the samples at $515 \mathrm{~nm}$.

The FRAP assay is widely used in food and is based on the reduction of the ferric to ferrous ions in the presence of an antioxidant. The FRAP working solution, freshly prepared, included the mixtures of $300 \mathrm{mM}$ acetate buffer $(50 \mathrm{ml})$, $10 \mathrm{mM}$ TPTZ (2,4,6-tripyridyl-s-triazine) $(5 \mathrm{ml})$ and $20 \mathrm{mM}$ $\mathrm{FeCl}_{3} \cdot 6 \mathrm{H}_{2} \mathrm{O}$ solution $(5 \mathrm{ml})$. The sample $(100 \mu \mathrm{l})$ was allowed to react with $500 \mu \mathrm{l} F R A P$ working solution and $2 \mathrm{ml}$ distilled water, for 1 hour in dark conditions. The colored product (ferrous tripyridyltriazine complex) at low $\mathrm{pH}$ was monitored by measuring the absorbance at $595 \mathrm{~nm}$ (Shimadzu $1240 \mathrm{mini}$ UV-Vis). Results were expressed in $\mu \mathrm{mol}$ Trolox equivalent (TE) $\bullet 100 \mathrm{~g}^{-1} \mathrm{FW}$.

\section{Analysis of volatile compounds of peaches and nectarines cultivars}

The extraction of volatile compounds from peach and nectarine fruit samples was performed using in-tube extraction technique (ITEX). Five grams from each sample were placed in a $20 \mathrm{ml}$ sealed headspace vial together with $0.6 \mathrm{~g} \mathrm{NaCl}$ and incubated for 30 minutes at $60^{\circ} \mathrm{C}$ under continuous agitation. The volatile compounds from the headspace phase of the vial were trapped using an ITEX fibre (ITEX-2 TrapTXTA, (G23)-Siliconert 2000, Tenax TA 80/100 mesh, Switzerland) and subsequently thermally desorbed into the GC injector $\left(250{ }^{\circ} \mathrm{C}\right.$ ). The separation of the volatile compounds was achieved on a Shimadzu GC-MS QP-2010 (Shimadzu Scientific Instruments, Kyoto, Japan) model gas chromatograph-mass spectrometer equipped with a CombiPALAOC-5000 autosampler (CTC Analytics, Zwingen, Switzerland). A ZB - $5 \mathrm{~ms}$ capillary column of $50 \mathrm{~m} \mathrm{x}$ $0.32 \mathrm{~mm}$ i.d. and $0.25 \mu \mathrm{m}$ film thickness was used for the separation. The program for the column oven temperature was: $40^{\circ} \mathrm{C}(3 \mathrm{~min})$ to $150^{\circ} \mathrm{C}$ at $5^{\circ} \mathrm{C} / \mathrm{min}$ (hold for $2 \mathrm{~min}$ ) and then to $220^{\circ} \mathrm{C}$ with $10^{\circ} \mathrm{C} / \mathrm{min}(10 \mathrm{~min})$. The carrier gas was helium $1.36 \mathrm{ml} / \mathrm{min}$, the ion source and interface temperatures were set at $250^{\circ} \mathrm{C}$ and the MS detector was used in EI mode in a scan range of $40-350 \mathrm{~m} / \mathrm{z}$. The identification of volatile compounds was carried out by comparing the obtained mass spectra with NIST27 and NIST147 library information and 
verified by comparison with retention indices drawn from www.pherobase.com or www.flavornet.org (for columns with a similar stationary phase to the ZB- $5 \mathrm{~ms}$ column). All peaks found in at least one of the three total ion chromatograms (TIC) of a sample were taken into account when calculating the total area of peaks (100\%) and the relative areas of the volatile compounds.

\section{Sample processing and pasteurisation treatment of juice fruits}

The nectarines and peach fruits were harvested at maturity consumption, weighed, measured and immediately processed for the analyses. To obtain the juice, the seeds of fruits were removed manually and the flesh was introduced into a commercial juice extractor. The fruit juice samples (obtained from 20 fruits) were placed in Erlenmeyer glass $(250 \mathrm{ml})$, covered with parafilm heated in a water bath at $80{ }^{\circ} \mathrm{C}$ for different time intervals: 15,20 and 25 minutes called as T15, T20, and T25, respectively. The time was monitored after the samples were immersed in the water-bath. The time T0, defines the juice fruit samples without pasteurisation. After cooling down at room temperature, in a water-bath (30 minutes), all the samples were centrifuged at $5000 \mathrm{rpm}$ for 20 minutes at $4{ }^{\circ} \mathrm{C}$, and supernatants were used for the analysis of total phenols content and antioxidant capacity by the procedures described above. All measurements were done for two samples in duplicates $(n=4)$. The results were expressed as mg GAE $\bullet 100 \mathrm{ml}^{-1}$ juice for total phenols, and $\mu \mathrm{mol}$ Trolox equivalent $(\mathrm{TE}) \bullet 100 \mathrm{ml}^{-1}$ juice, for antioxidant capacity.

\section{Statistical analysis}

One-way ANOVA ( $p \leq 0.05)$ was done for the cultivar parameters that define the fruits. Two-way ANOVA ( $\mathrm{p} \leq$ 0.05 ) was done in order to analyse the differences generated by the factor Cultivar and Pasteurisation Time. In order to express the means differences, for both ANOVA variants the multi comparisons post-hoc Tukey's test $(\mathrm{p} \leq 0.05)$ were generated. Both the analyses of variance tests were done with MiniTab 16 (MiniTab Inc., PA 16801-3210, USA). Multivariate analysis was performed in order to determine which fruits present the highest phenolic compounds and antioxidant capacity. Principal Component Analysis (PCA) and Hierarchical Cluster Analysis (HCA) were applied as multivariate ordination and tests. For these statistical analyses PAST version 3.05 software was used (Hammer and Harper, 2013).

\section{Results and Discussion}

\section{Fruit quality parameters}

The fruits quality parameters tested were found to show considerable variations (Table 1). Fruit ripening time covered a period between the middle of July and the 20th August in the case of nectarines, and the 8th July and the 12th August in the case of peaches, encompassing early and medium-ripening cultivars. Early ripening cultivars were 'Cardinal', 'Collins', 'Jerseyland' and 'Romamer'. Among medium ripening cultivars, the fruits with harvest date after 15 th July were considered. Average fruit weight ranged between $57.85 \pm 6.69 \mathrm{~g}$ and 200.00 $\pm 8.99 \mathrm{~g}$ for peach cultivars 'Cardinal' and 'Southland', respectively, and $61.43 \pm 19.84 \mathrm{~g}$ and $89.57 \pm 19.51$ $\mathrm{g}$ for nectarine cultivars 'Ark 125' and 'Romamer', respectively (Table 1). The highest SSC values were observed in peach cultivars, particularly in 'Amalia', 'Antonia' and 'Jerseyland' $\left(18.09 \pm 0.12,16.48 \pm 0.04\right.$ and $16.46^{\circ}$ Brix, respectively). The values of SSC were similar to those obtained to Legua et al. (2011), for peach and nectarine cultivars in the year 2009 at Cieza (Murcia, Spain). All SCC values were over $8{ }^{\circ}$ Brix, which is considered the minimum SCC established by the European Union to market peach and nectarines (Commission Regulation (EC) no. 1221/2008 of December 5, 2008). SSC in fruits are mainly due to the sugars sucrose, glucose and fructose, which comprise about $60 \%$ of the SSC in ripe peaches (Abidi et al., 2011). In general, early-ripening cultivars showed lower SSC values than medium-ripening cultivars, suggesting that the latter cultivars have a great capacity to accumulate sugars. The 'Southland' cultivar showed the highest titratable acidity values, while the 'Antonia' recorded the lowest values of TA $(2.63 \pm 0.17$ and $1.12 \pm 0.01 \mathrm{~g}$ malic acid $.100 \mathrm{~g}^{-1} \quad$ FW respectively). The ripening indexes ( $\mathrm{RI}=\mathrm{SSC} / \mathrm{TA})$ were the lowest in nectarine cultivar 'Ark 125', and highest in 'Antonia' and 'Amalia' peach cultivars (Table 1). This index is an important organoleptic quality aspect of the mature fruit (Petrisor et al., 2010). The $\mathrm{pH}$ values varied from $3.97 \pm 0.08$ to $4.77 \pm 0.02$ with a mean value of 4.36 and 4.34 for nectarine and peaches, respectively. The cultivars tested had a $\mathrm{pH}$ value higher than 4.0 at maturity, and are considered nonacid (Abidi et al., 2011).

Table 1. Origin, fruit weight $(\mathrm{g})$ and diameter $(\mathrm{mm})$, soluble solid content (SSC, oBrix), pH, titrable acidity (TA, g malic acid 100 g-1 FW) and SSC/TA ratio of peach and nectarine cultivars analyzed

\begin{tabular}{|c|c|c|c|c|c|c|c|}
\hline Cultivar & Origin & Weight & Diameter & SSC & $\mathrm{pH}$ & TA & SSC/TA \\
\hline 'Amalia' & $\mathrm{RO}$ & $161.10 \pm 9.99 \mathrm{a}$ & $60.60 \pm 3.17 \mathrm{a}$ & $18.09 \pm 0.12 \mathrm{a}$ & $4.44 \pm 0.02 b$ & $1.29 \pm 0.03 \mathrm{ef}$ & $14.07 \pm 0.37 \mathrm{a}$ \\
\hline 'Antonia' & $\mathrm{RO}$ & $180.00 \pm 10.33 \mathrm{ab}$ & $46.70 \pm 1.89 b$ & $16.48 \pm 0.04 b$ & $4.48 \pm 0.08 b$ & $1.12 \pm 0.01 \mathrm{f}$ & $14.70 \pm 0.17 \mathrm{a}$ \\
\hline 'Ark 125' & USA & $61.43 \pm 19.84 b c$ & $45.92 \pm 5.72 b c$ & $10.07 \pm 0.10 \mathrm{de}$ & $4.28 \pm 0.02 \mathrm{~cd}$ & $2.39 \pm 0.01 b$ & $4.21 \pm 0.05 b$ \\
\hline 'Cardinal' & USA & $57.85 \pm 6.69 \mathrm{bc}$ & $46.30 \pm 2.47 c$ & $9.75 \pm 0.13 \mathrm{f}$ & $4.77 \pm 0.02 \mathrm{a}$ & $1.50 \pm 0.03 \mathrm{~d}$ & $6.50 \pm 0.19 c$ \\
\hline 'Collins' & USA & $69.38 \pm 17.98 c$ & $48.38 \pm 5.00 \mathrm{~d}$ & $10.02 \pm 0.07 \mathrm{e}$ & $4.23 \pm 0.04 d$ & $2.02 \pm 0.08 c$ & $4.97 \pm 0.20 \mathrm{~d}$ \\
\hline 'Crimsongold' & USA & $65.64 \pm 17.17 \mathrm{~d}$ & $46.56 \pm 4.51 \mathrm{e}$ & $10.30 \pm 0.08 \mathrm{~d}$ & $4.39 \pm 0.08 \mathrm{bcd}$ & $1.93 \pm 0.08 \mathrm{c}$ & $5.35 \pm 0.26 \mathrm{~d}$ \\
\hline 'Jerseyland' & USA & $170.80 \pm 12.39 \mathrm{e}$ & $69.70 \pm 2.36 \mathrm{e}$ & $16.46 \pm 0.09 b$ & $4.49 \pm 0.05 b$ & $1.28 \pm 0.05$ ef & $12.91 \pm 0.52 \mathrm{e}$ \\
\hline 'Redhaven' & USA & $150.60 \pm 5.40 \mathrm{e}$ & $64.70 \pm 3.43 \mathrm{e}$ & $13.34 \pm 0.09 c$ & $3.97 \pm 0.08 \mathrm{e}$ & $1.45 \pm 0.08 \mathrm{de}$ & $9.23 \pm 0.48$ ef \\
\hline 'Romamer' & $\mathrm{RO}$ & $89.57 \pm 19.51 \mathrm{e}$ & $53.34 \pm 4.40 \mathrm{e}$ & $10.12 \pm 0.13 \mathrm{de}$ & $4.43 \pm 0.10 b c$ & $2.40 \pm 0.06 b$ & $4.22 \pm 0.09 f$ \\
\hline 'Southland' & USA & $200.00 \pm 8.99 \mathrm{e}$ & $89.70 \pm 4.62 \mathrm{e}$ & $16.40 \pm 0.13 b$ & $4.03 \pm 0.06 \mathrm{e}$ & $2.63 \pm 0.17 \mathrm{a}$ & $6.26 \pm 0.42 \mathrm{f}$ \\
\hline
\end{tabular}


Total phenols content and antioxidant capacity of peach and nectarine cultivars

Total phenols content (Fig. 1) and antioxidant capacity (DPPH and FRAP values) (Fig. 2) were measured in a wide range of cultivars (peach and nectarine). With respect to the total phenols content, the peach cultivars with the highest concentration were 'Southland', followed by 'Jerseyland' and 'Redhaven' (47.49 $\pm 0.14 \mathrm{mg} \mathrm{GAE} 100 \mathrm{~g}^{-1} \mathrm{FW} ; 42.24 \pm 0.44 \mathrm{mg}$ GAE $100 \mathrm{~g}^{-1} \mathrm{FW} ; 36.82 \pm 0.74 \mathrm{mg}$ GAE $100 \mathrm{~g}^{-1}$, respectively). The nectarine cultivars showed lower content in phenols comparative with peaches. Between the nectarine cultivars the highest content in total phenols were recorded in 'Romamer', followed by 'Crimsongold' and 'Ark 125' (16.28 $\pm 0.83 \mathrm{mg}$ GAE $100 \mathrm{~g}^{-1} \mathrm{FW} ; 15.07 \pm 0.61 \mathrm{mg}$ GAE $100 \mathrm{~g}^{-1} \mathrm{FW}$; $12.57 \pm 0.72 \mathrm{mg}$ GAE $100 \mathrm{~g}^{-1} \mathrm{FW}$, respectively). The results are in accordance with other research studies [Abidi et al., 2011; Legua et al., 2011; Stojanovic et al., 2016]. According to Vizzotto et al. (2014) the main compounds in four peach genotypes are hydroxycinnamic acid derivatives including chlorogenic acid and a caffeic acid derivative, which is likely neo-chlorogenic acid. The agro-climatic conditions, irrigation and fertilization can affect the bioactive compounds of fruits (Vizzotto et al., 2014). However, in this study, all cultivars were grown under the same environmental conditions and cultural practices, significant differences in the content of total phenols were found among the studied peaches and nectarines cultivars.

The antioxidant capacity was determined in both peach and nectarine cultivars using two different methods, DPPH and FRAP (Fig. 2). The highest antioxidant capacities were recorded in 'Southland' peach $(79.45 \pm 0.00 \%$, and $453.07 \pm 1.49 \mu \mathrm{mol}$ TE $100 \mathrm{~g}^{-1} \mathrm{FW}, \mathrm{DPPH}$ and FRAP values, respectively). The lowest antioxidant capacity was found for 'Ark 125 ' nectarine cultivar (15.79 $\pm 1.16 \%$ inhibition of DPPH radical and $62.18 \pm 2.87 \mu \mathrm{mol}$ TE $100 \mathrm{~g}^{-1} \mathrm{FW}$, respectively).

From our results it is difficult to define a clear trend in terms of antioxidant capacity among the fruit groups (peach and nectarine). Also, this remark was reported by previous studies (Gil et al., 2002; Tavarini et al., 2008; Stojanovic et al., 2016) showing that the antioxidant capacity is more likely related to individual cultivars rather than group cultivars.

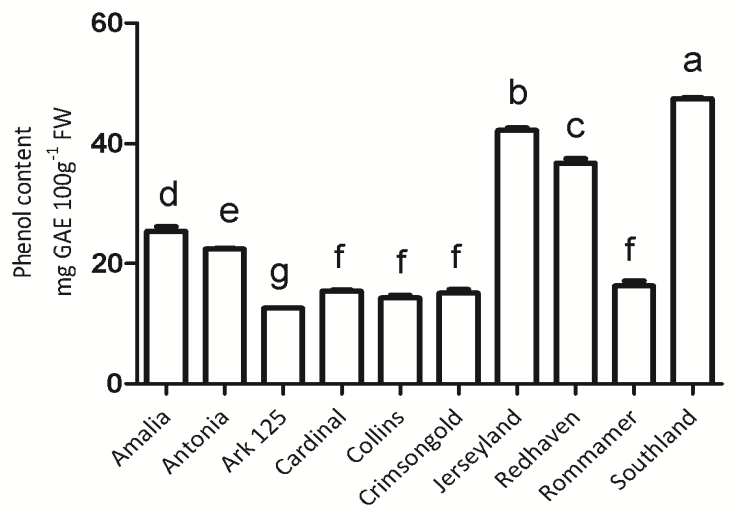

Fig. 1. Total Phenols content of peach and nectarines cultivars. Each value is the mean of three replicates. Bars indicate standard deviations. Means with the same letter are not significantly different for $\mathrm{P}=0.05$ following a one-way ANOVA test

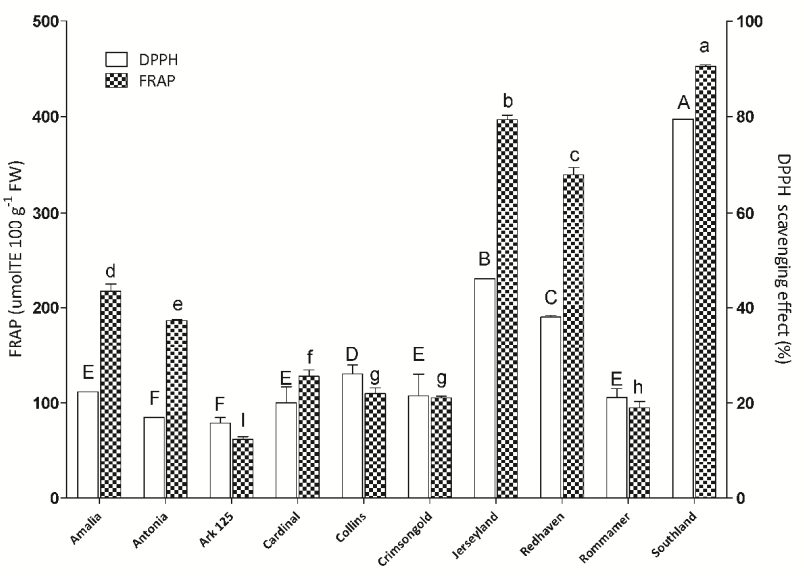

Fig. 2. Antioxidant capacity of peach and nectarines cultivars. Each value is expressed as mean and bars indicate standard deviations. Capital and small letters are describing means statistical differences in the case of values obtained by DPPH and FRAP assay, respectively. Means with the same letter are not significantly different for $\mathrm{P}=0.05$ following a one-way ANOVA test

\section{The volatile composition of peach and nectarine cultivars}

Beside the fruit firmness and colour, consumers consider the aroma to be another essential factor that contributes to the quality of peaches and nectarines. The flavour of fruits is defined by the taste imparted by the basic organic components (sugars, organic acids) and by the volatile aroma compounds (Sánchez et al., 2012). The volatile composition of peaches and nectarines has been intensively studied, and over 100 compounds were identified (Wang et al., 2009). Our study was focused on the characterisation of the volatile profile of seven peach cultivars and three nectarine cultivars, cultivated in Romania. The determined volatile composition of the analyzed peach and nectarine samples via the ITEX/GC-MS technique is presented in Table 2 . The volatile compounds include alcohols, aldehydes, esters and lactones. For both peach and nectarine samples, the main volatile compounds belong to alcohols and aldehydes.

The nectarine samples were characterized by a high level of alcohols (87.63-94.43\%), the main ones being 1-hexanol (over 65\%), 3-methyl-1-butanol and 2-methyl-1-butanol. In the case of the peach samples, the above mentioned alcohols are also the major ones found, but their levels and ratios varied significantly between samples. Thus, 'Collins' and 'Cardinal' cultivars presented very high levels of 1-hexanol $(84.96 \%$ and $43.49 \%$ respectively) compared with the other peach cultivars, for which the content of this compound was between 3.90-9.79\%.

Besides 1-hexanol, other four compounds from the group of C6 were identified in the peach and nectarine samples, including: (E)-3-hexen-1-ol, (Z)-2-hexen-1-ol, hexanal and (E)-2-hexenal. These compounds are known as green compounds due to the fact that they impart a 'grassy' flavour, their concentration usually being higher in immature fruits (Kralj et al., 2014). On the other hand, the $\mathrm{C} 6$ compounds are formed by the enzyme-catalyzed breakdown of unsaturated fatty acids (Wang et al., 2009). The high levels of 1-hexanol and hexanal found in some of the analyzed peach and nectarine samples are probably due to the breakdown of fatty acids. 
Table 2. Mean relative concentrations (expressed as \% from total peak areas) of volatile compounds detected in peach and nectarine samples analyzed by ITEX/GC-MS

\begin{tabular}{|c|c|c|c|c|c|c|c|c|c|c|}
\hline Compound & 'Amalia' & 'Antonia' & 'Ark 125' & 'Cardinal' & 'Collins' & 'Crimsongold' & 'Jerseyland' & 'Redhaven' & 'Romamer' & 'Southland' \\
\hline \multicolumn{11}{|c|}{ Alcohols } \\
\hline 1-Penten-3-ol & 1.41 & 3.66 & 0.31 & 0.00 & 0.00 & 0.52 & 3.00 & 1.27 & 0.58 & 0.00 \\
\hline 3-Pentanol & 0.00 & 2.94 & 0.23 & 0.34 & 0.03 & 0.75 & 0.00 & 0.00 & 0.40 & 0.00 \\
\hline $\begin{array}{c}\text { 3-Methyl-1- } \\
\text { butanol }\end{array}$ & 6.82 & 1.30 & 15.14 & 33.73 & 3.16 & 15.69 & 0.00 & 0.51 & 5.40 & 0.00 \\
\hline $\begin{array}{l}\text { 2-Methyl- } 1 \text { - } \\
\text { butanol }\end{array}$ & 12.69 & 4.74 & 7.90 & 17.67 & 2.29 & 9.41 & 1.70 & 1.47 & 2.59 & 0.00 \\
\hline 1-Pentanol & 1.59 & 0.00 & 0.06 & 0.00 & 0.00 & 0.24 & 0.00 & 0.95 & 0.00 & 0.00 \\
\hline $\begin{array}{c}\text { (E)-3-Hexen- } \\
\text { 1-ol }\end{array}$ & 0.00 & 0.00 & 0.15 & 0.71 & 0.99 & 0.00 & 0.84 & 0.00 & 0.20 & 0.00 \\
\hline $\begin{array}{c}\text { (Z)-2-Hexen- } \\
\text { 1-ol }\end{array}$ & 0.00 & 0.00 & 0.00 & 0.00 & 0.00 & 0.00 & 0.00 & 1.78 & 0.23 & 0.00 \\
\hline 1-Hexanol & 3.90 & 7.78 & 69.08 & 43.49 & 84.96 & 65.51 & 7.40 & 8.89 & 85.03 & 9.79 \\
\hline Phenol & 0.79 & 2.58 & 0.00 & 0.00 & 0.00 & 0.00 & 1.03 & 0.00 & 0.00 & 1.75 \\
\hline $\begin{array}{l}\text { 2-Ethyl-1- } \\
\text { hexanol }\end{array}$ & 2.19 & 0.79 & 0.00 & 0.00 & 0.00 & 0.00 & 2.74 & 1.79 & 0.00 & 1.11 \\
\hline Total & 29.39 & 23.79 & 92.87 & 95.94 & 91.43 & 92.12 & 16.71 & 16.66 & 94.43 & 12.65 \\
\hline \multicolumn{11}{|c|}{ Aldebydes } \\
\hline $\begin{array}{l}\text { 2-Methyl- } \\
\text { butanal }\end{array}$ & 2.34 & 1.72 & 0.00 & 0.00 & 0.00 & 0.00 & 0.00 & 0.00 & 0.00 & 0.00 \\
\hline Pentanal & 8.26 & 8.96 & 0.17 & 0.00 & 0.27 & 0.36 & 5.85 & 3.12 & 0.16 & 7.91 \\
\hline Hexanal & 35.25 & 35.11 & 1.45 & 1.28 & 2.55 & 1.43 & 33.03 & 17.10 & 1.86 & 34.38 \\
\hline Furfural & 0.00 & 3.87 & 0.00 & 0.00 & 0.00 & 0.00 & 0.00 & 0.00 & 0.00 & 0.00 \\
\hline (E)-2-Hexenal & 2.17 & 1.38 & 0.14 & 0.00 & 0.85 & 0.22 & 1.97 & 1.73 & 1.43 & 4.12 \\
\hline Heptanal & 1.20 & 1.62 & 0.00 & 0.00 & 0.26 & 0.00 & 0.00 & 0.00 & 0.00 & 0.90 \\
\hline Benzaldehyde & 5.05 & 16.91 & 0.51 & 1.71 & 1.62 & 0.56 & 28.36 & 45.48 & 0.58 & 31.60 \\
\hline Octanal & 0.63 & 0.00 & 0.00 & 0.00 & 0.00 & 0.00 & 0.00 & 0.00 & 0.00 & 0.00 \\
\hline Nonanal & 2.00 & 2.13 & 0.00 & 0.00 & 0.00 & 0.00 & 0.00 & 0.00 & 0.00 & 1.37 \\
\hline Total & 56.90 & 71.70 & 2.27 & 2.99 & 5.55 & 2.57 & 69.21 & 67.43 & 4.03 & 80.28 \\
\hline \multicolumn{11}{|c|}{ Ketones } \\
\hline 2-Pentanone & 0.00 & 0.00 & 0.34 & 0.00 & 1.14 & 0.00 & 0.00 & 0.00 & 0.00 & 0.00 \\
\hline 2-Heptanone & 0.00 & 0.00 & 0.00 & 0.00 & 1.25 & 0.00 & 0.00 & 0.00 & 0.00 & 0.00 \\
\hline $\begin{array}{l}\text { 6-Methyl-5- } \\
\text { heptene-2-one }\end{array}$ & 1.07 & 0.66 & 0.00 & 0.00 & 0.00 & 0.00 & 0.00 & 0.81 & 0.00 & 0.00 \\
\hline 2-Octanone & 0.00 & 0.00 & 0.00 & 0.00 & 0.28 & 0.00 & 0.00 & 0.00 & 0.00 & 0.00 \\
\hline Acetophenone & 3.28 & 3.90 & 0.00 & 0.00 & 0.00 & 0.00 & 4.04 & 3.11 & 0.00 & 2.85 \\
\hline Total & 4.35 & 4.56 & 0.34 & 0.00 & 2.67 & 0.00 & 4.04 & 3.92 & 0.00 & 2.85 \\
\hline \multicolumn{11}{|c|}{ Esters } \\
\hline $\begin{array}{c}\text { Ethyl } \\
\text { propanoate }\end{array}$ & 0.00 & 0.00 & 0.25 & 0.48 & 0.00 & 0.51 & 0.00 & 0.00 & 0.00 & 0.00 \\
\hline $\begin{array}{l}\text { n-Propyl } \\
\text { acetate } \\
2-\end{array}$ & 0.00 & 0.00 & 0.95 & 0.00 & 0.00 & 1.72 & 0.00 & 0.00 & 0.00 & 0.00 \\
\hline $\begin{array}{l}\text { Methylpropyl } \\
\text { acetate }\end{array}$ & 4.86 & 0.00 & 0.71 & 0.00 & 0.00 & 1.78 & 0.00 & 0.00 & 0.20 & 0.00 \\
\hline $\begin{array}{c}\text { Ethyl } \\
\text { butanoate }\end{array}$ & 0.00 & 0.00 & 0.00 & 0.00 & 0.00 & 0.00 & 0.00 & 0.00 & 0.00 & 0.00 \\
\hline $\begin{array}{c}\text { 2-Methyl } \\
\text { ethyl } \\
\text { butanoate }\end{array}$ & 0.00 & 0.00 & 0.00 & 0.28 & 0.00 & 0.00 & 0.00 & 0.00 & 0.00 & 0.00 \\
\hline $\begin{array}{l}\text { 3-Methyl-1- } \\
\text { butanol } \\
\text { acetate }\end{array}$ & 0.00 & 0.00 & 0.35 & 0.34 & 0.00 & 0.26 & 0.00 & 0.00 & 0.00 & 0.00 \\
\hline $\begin{array}{l}\text { (Z)-4-Hexen- } \\
\text { 1-ol acetate }\end{array}$ & 0.00 & 0.00 & 0.00 & 0.00 & 0.00 & 0.00 & 3.84 & 2.50 & 0.00 & 0.00 \\
\hline Hexyl acetate & 0.00 & 0.00 & 2.31 & 0.00 & 0.40 & 1.06 & 6.25 & 0.00 & 1.39 & 2.50 \\
\hline$\gamma$-Decalactone & 1.25 & 0.00 & 0.00 & 0.00 & 0.00 & 0.00 & 0.00 & 0.00 & 0.00 & 0.00 \\
\hline Total & 6.11 & 0.00 & 4.57 & 1.10 & 0.40 & 5.33 & 10.09 & 2.50 & 1.59 & 2.50 \\
\hline \multicolumn{11}{|c|}{ Others } \\
\hline $\begin{array}{c}2,4,5- \\
\text { trimethyl-1,3- } \\
\text { Dioxolane }\end{array}$ & 2.89 & 0.00 & 0.00 & 0.00 & 0.00 & 0.00 & 0.00 & 0.00 & 0.00 & 0.00 \\
\hline $\begin{array}{c}\text { 2-n- } \\
\text { Pentylfuran } \\
\text { (Z)-3-Methyl }\end{array}$ & 0.41 & 0.00 & 0.00 & 0.00 & 0.00 & 0.00 & 0.00 & 0.00 & 0.00 & 0.00 \\
\hline $\begin{array}{c}1,3- \\
\text { pentadiene }\end{array}$ & 0.00 & 0.00 & 0.00 & 0.00 & 0.00 & 0.00 & 0.00 & 0.00 & 0.00 & 1.75 \\
\hline Eucalyptol & 0.00 & 0.00 & 0.00 & 0.00 & 0.00 & 0.00 & 0.00 & 9.53 & 0.00 & 0.00 \\
\hline Total & 3.30 & 0.00 & 0.00 & 0.00 & 0.00 & 0.00 & 0.00 & 9.53 & 0.00 & 1.75 \\
\hline
\end{tabular}


558

A total of nine aldehydes were identified in the studied samples, among them hexanal, benzaldehyde and pentanal being the major ones, especially in the peach samples. Benzaldehyde was found in large concentrations (16.91$45.48 \%$ ) in four of the peach cultivars ('Antonia', 'Jerseyland', 'Redhaven' and 'Southland'), while in nectarine samples its level was considerably lower (0.51-0.58\%). Even though benzaldehyde was identified in different vegetable matrices and it imparts an almond-like or peach stone like aroma, its origin was not completely elucidated yet. Aubert and Milhet (2007) mentioned three possible pathways, the most probable one being the enzymatic hydrolysis of amygdalin, a cyanogenic glycoside present in the stone.

Esters are considered to have an important contribution to the fruity and floral aroma of foods, thus giving pleasant flavour attributes (Sumitani et al., 1994; Wang et al., 2009). Nine esters were identified in the samples of peaches and nectarines analyzed. Their concentration ranged between $0.40 \%$ and $10.09 \%$ for peach samples, while for the nectarine samples, their level was between $1.59 \%$ and $5.33 \%$. The 'Jerseyland' peaches and the 'Crimsongold' nectarines had the highest content in esters. The main representatives of ester group found in peaches were acetates, including 2-methylpropyl acetate, (Z)-4-hexen-1-ol acetate and hexyl acetate. In nectarine samples, hexyl acetate, 2-methylpropyl acetate and n-propyl acetate were the main detected esters. Gamma-decalactone, which is a typical compound that contributes to the "peachy" aroma (Wang et al., 2009; Kralj et al., 2014) was found in only one of the peach samples, namely 'Amalia'. The content in lactones, especially in $\gamma$-decalactone and $\delta$-decalactone, usually increases during ripening, these compounds being responsible for the increase in the fruity and creamy characteristic notes while the content in $\mathrm{C} 6$ compounds (responsible for the green notes) decreases (Kralj et al., 2014).

Effect of pasteurisation on total phenols content and antioxidant capacity of peach and nectarine juices

Peaches and nectarines especially are very perishable, and for this reason industrial fruit manufacturing processes the fresh fruits as juices that are often thermally treated by pasteurisation. This thermal process is the most common technique currently used to inactivate the vegetative forms of spoilage microorganisms or human pathogens (Oliveira et al., 2012). In the present study, the effect of pasteurisation $\left(80^{\circ} \mathrm{C}\right)$ for different time periods $(0,15,20$ and 25 minutes) on peach and nectarine juices was assessed in order to establish the best time to liberate the phenolic compounds with high antioxidant properties (Table 3).

The nectarine and peach juices, after pasteurisation at different time periods, showed a significant increase in total phenols content compared with fresh juice fruits. From three nectarine juices studied, 'Crimsongold' has the highest content in phenols after 15 minutes of pasteurisation $(19.29 \pm 0.61 \mathrm{mg}$ GAE•100 $\mathrm{ml}^{-1}$ vs. $29.87 \pm 2.28 \mathrm{mg} \mathrm{GAE} 100 \mathrm{ml}^{-1}$, at T0 and T15, respectively). Conversely, in the case of 'Romamer' and 'Ark 125' juices, the highest phenols content was recorded after 25 and 20 minutes respectively. In the case of peach juices, in the samples submitted to pasteurisation the highest content in total phenols was recorded at 25 minutes of pasteurisation, except 'Collins' and 'Southland', where the highest total phenols were recorded at 15 minutes.

Some research studies (Bhattacherjee et al., 2011; Oliveira et al., 2012; Oliveira et al., 2014) showed that both phenols content and antioxidant activity are not significantly modified by pasteurisation, but these studies have only allowed the samples for a maximum of 10 minutes of pasteurisation, generally at higher temperatures than those studied in this article. Bhattacherjee et al. (2011) through their study on the effect of different pasteurisation temperatures on aonla juice, have reached the conclusion that the $80{ }^{\circ} \mathrm{C}$ temperature is optimal in order to obtain juice rich in bioactive compounds.

Regarding the individual phenols, Oliveira et al. (2012) have shown that the levels of rutin, (+)-catechin, (-)epicatechin and procyanidin B1, as well as hydroxycinnamin acid derivatives were not significantly affected by pasteurisation.

The antioxidant capacity of fruit juices varied in relation to the time of pasteurisation, significant increases being recorded between the initial time (fresh juice) and the final time of pasteurisation (T25). The results are correlated with the content of phenolic compounds.

The processing of fruits by heating causes the rupture of cell walls, exposing the bioactive compounds in their juice. Oliveira et al. (2012) reported that the content of individual phenolics like as rutin, (+)-catechin, (-) epicatechin, and procyanidin B1 was not significatly affected by pasteurisation at $90{ }^{\circ} \mathrm{C}$ for 5 minutes. Also, the pasteurisation of fresh peaches has no significant effect on hydroxycinnamic acid derivatives, but significantly reduces the content of protocatechuic acid.

\section{Multivariate analysis}

Univariate analysis (ANOVA tests) reveals the fruits (peaches and nectarines) and its pasteurized juices that present the highest content strictly in terms of the total phenols content (TPh) or for one of the antioxidant capacity (DPPH or FRAP). Fig. 3 shows the PCA biplot for group ordination of fruits denoted for interaction factor Cultivar and three variables: total phenols content, DPPH and FRAP. First

Table 3. Total phenols $(\mathrm{TPh})$ and antioxidant capacity $(\mathrm{DPPH}$ and FRAP $)$ determined at different pasteurization time $(\mathrm{T} 0=$ without pasteurisation, $\mathrm{T} 15=15 \mathrm{~min}, \mathrm{~T} 20=20 \mathrm{~min}$ and $\mathrm{T} 25=25 \mathrm{~min}$ )

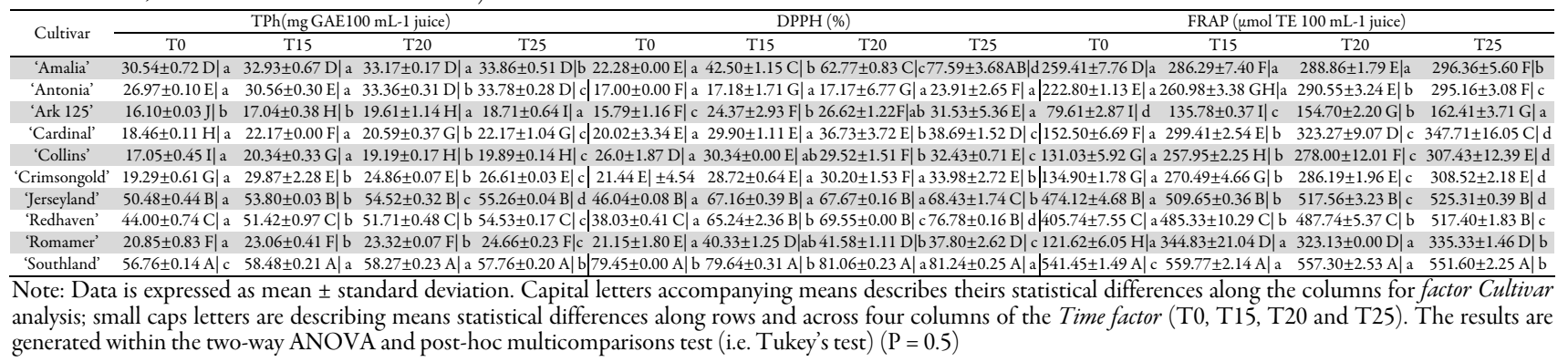


principal axis PC1 explains $94.6 \%$ of total variability and second principal axis $5.2 \%$, thus gathering $99.8 \%$ of total variability. Variables TPh and FRAP present overlapping vectors as these variables are strongly correlated $(R=0.9946$ and $\mathrm{p}<0.0001)$. These variables are positive loaded with PC1 and negative loaded with PC2. Variable DPPH is positive loaded with both PC1 and PC2 principal component axis, but is strongly correlated just with PC2 axis. In the PCA biplot the cultivars 'Redhaven', 'Jerseyland', 'Amalia' and 'Antonia' are positively loaded with the TPh and FRAP, in contrast with the rest of the cultivars. In the same way, the cultivars 'Southland', 'Collins', 'Crimsongold', 'Ark165', 'Romamer' and 'Cardinal' are positively loaded by the DPPH variable, displaying higher scavenging effect of DPPH radicals than the other cultivars.

In order to find the optimal pasteurisation time (T0, T15, T20 and T25) to maintain the high levels of phenolic compounds and antioxidant capacity, data was subjected to multivariate analyses. The HCA results generated three clusters (Fig. 4) which are validated by MANOVA $(\mathrm{p}=0.05)$ (data not shown). The \# 1 cluster is the one that is positively loaded with canonical Axis 1 and all three variable vectors, and presents the highest content of variables (FRAP, TPh and DPPH). In the second cluster (\#2), cultivars 'Antonia' and 'Amalia' time profiles present shifts within the cluster. The third cluster (\#3) contains all the time profiles of the 'Redhaven', 'Jerseylandand', 'Southland' cultivars. From these three cultivars, 'Southland' presents the highest robustness to pasteurization time, as it displays the lowest shift content (i.e. coordinates variation) parallel, next to canonical Axis 1. The other two cultivars, present wider shifts of time profiles, with the pasteurization time in the Axis 1 positive direction. All the time profiles shifting directions are parallel with the FRAP and DPPH vectors' positive directions, thus the pasteurization main effects are prescribed by these two parameters.

These data represent the first systematic study regarding the composition of peach and nectarine juice cultivars based on bioactive phytochemicals and their antioxidant capacity.

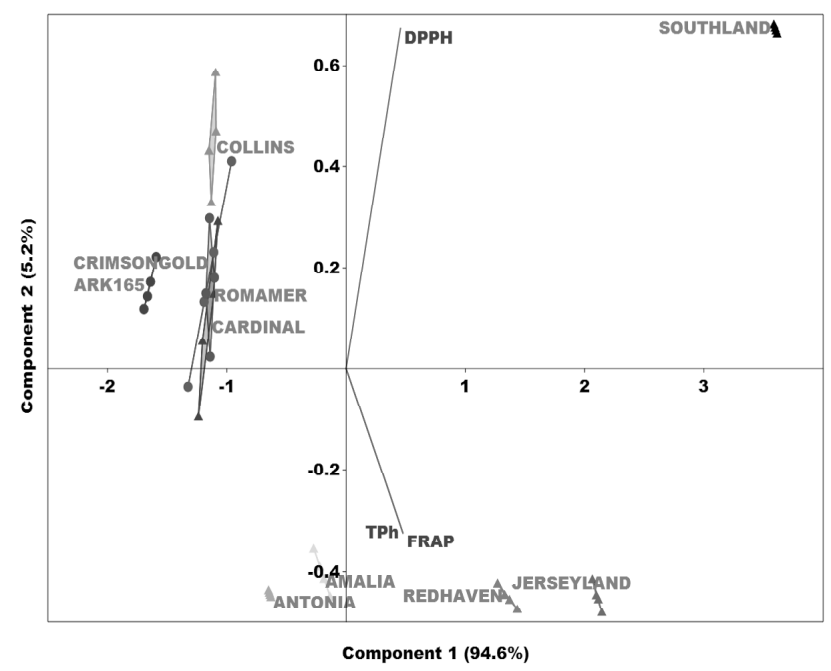

Fig. 3. Biplot of Principal Component Analysis (PCA) results of factor Cultivar (peaches and nectarines) and three variables: $\mathrm{TPh}$ (total phenols content), DPPH and FRAP (PC1: 94.6\%, PC2: $5.2 \%, 99.8 \%$ of total variability)

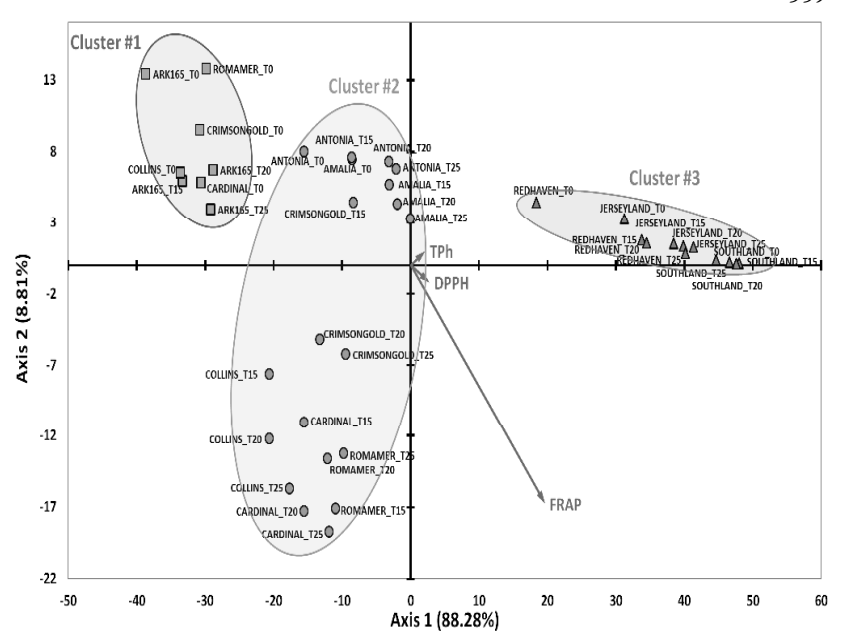

Fig. 4. The biplot of CVA results with HCA clustering information (ellipses for each cluster) for the four time of pasteurisation (T0, T15, T20 and T25)

\section{Conclusions}

In this study it is showed that the peach and nectarine cultivars growing in the N-W part of Romania are rich in phenolic compounds with antioxidant capacity, and that the pasteurisation process at $80{ }^{\circ} \mathrm{C}$, for more than 15 minutes, increases the level of these compounds. Among the peach cultivars, 'Southland' followed by 'Jerseyland' and 'Redhaven' recorded the highest total phenols content. From nectarine cultivars, 'Romamer' recorded the highest total phenols content. The nectarine cultivars showed lower content in phenols comparative with peaches. The nectarine samples were characterized by a high level of alcohols (87.63-94.43\%), the main ones being 1-hexanol. In the peach cultivars, also the alcohols are the major, but their levels and ratios varied significantly between samples.

The pasteurisation process (at low temperature but for a longer period of time) has a double effect, inactivating the unwanted microflora and enzymes (like polyphenol oxidase), while at the same time liberating the phenolic compounds from the fruit matrix. It is important to establish the impact of certain processing factors upon bioactive compounds present in complex fruit matrices, to select the best conditions to obtain the products with highest levels of phenolic compounds with antioxidant capacity.

\section{Acknowledgements}

This work was supported by the Romanian National Authority for Scientific Research, CNDI-UEFISCDI, under grant PN-II-IN-CI-2012-1-0255.

\section{References}

Abidi W, Jimenez S, Moreno M, Gogorcena Y (2011). Evaluation of Antioxidant Compounds and Total Sugar Content in a Nectarine [Prunuspersica (L.) Batsch] Progeny. International Journal of Molecular Sciences 12:6919-6935. 
560

Aubert C, Milhet C (2007). Distribution of the volatile compounds in the different parts of a white-fleshed peach (Prunus persica L. Batsch). Food Chemistry 102:375-384.

Benzie IF, Strain JJ (1996). The ferric reducing ability of plasma (FRAP) as a measure of "antioxidant power". The FRAP assay. Analytical Biochemistry 239:70-76.

Bhattacherjee AK, Tandon DK, Dikshit A, Kumar S (2011). Effect of pasteurization temperature on quality of aonla juice during storage. Journal of Food Science and Technology 48:269-273.

European Fruit Juice Association (2016). Liquid fruit, market report. Retrieved 2016December 10 from www.aijn.org

Food and Agriculture Organisation of the United Nations (2016). Retrieved 2016 March 15 from http://faostat3.fao.org/download/Q/QC/E.

Gil MI, Tomas-Barberan FA, Hess-Pierce B, Kader AA (2002). Antioxidant capacities, phenolic compounds, carotenoids, and vitamin $C$ contents of nectarine, peach, and plum cultivars from California. Journal of Agricultural and Food Chemistry 50:4976-4982.

Hammer Ø, Harper DAT (2005). Paleontological Data Analysis. WileyBlackwell Publishing Malden, MA, USA.

Hegedus A, Engel R, Abranko L, Balogh E, Blazovics A, Herman R, Halasz J, Ercisli S, Pedryc A, Stefanovits-Banyai E (2010). Antioxidant and antiradical capacities in apricot (Prunus armenica L.) fruits: variations from genotypes, years, and analytical methods. Journal of Food Science 75:C722-C730.

Kowalski S, Lukasiewicz M, Duda-Chodak A, Zięć G (2013). 5Hydroxymethyl-2-Furfural (HMF) - Heat-Induced Formation, Occurrence in Food and Biotransformation - a Review. Polish Journal of Food and Nutrition Sciences 63:207-225.

Kralj MB, Jug T, Komel E, Fajt N, Jarni K, Živković J, Mujić, I (2014). Aromatic compound in different peach cultivars and effect of preservatives on the final aroma of cooked fruits. Hemijska Industrija 68:767-779.

Legua P, HernándezF, Díaz-Mula H, Valero D, Serrano M (2011). Quality, Bioactive Compounds, and Antioxidant Activity of New Flat-Type Peach and Nectarine Cultivars: A comparative study. Journal of Food Science 76:C729-C735.

Lemmens L, De Vleeschouwer K, Moelants KRN, Colle IJP, Van Loey AM, Hendrickx ME (2010). Beta-carotene isomerization kinetics during thermal treatments of carrot puree. Journal of Agricultural and Food Chemistry 58:6816-6824.

Lemmens L, Van Buggenhout S, Oey I, Van Loey A, Hendrickx M (2009). Towards a better understanding of the relationship between the betacarotenein vitro bio-accessibility and pectin structural changes: A case study on carrots. Food Research International 42:1323- 1330.

Leontowicz H, Gorinstein S, Lojek A, Leontowicz M, Ciz M, SolivaFortuny R, Park YS, Jung ST, Trakhtenberg S, Martin-Belloso O (2002). Comparative content of some bioactive compounds in apples, peaches and pears and their influence on lipids and antioxidant capacity in rats. The Journal of Nutritional Biochemistry 13:603-610.
Lutz M, Hernández J, Henríquez C (2015). Phenolic content and antioxidant capacity in fresh and dry fruits and vegetables grown in Chile. CyTA-Journal of Food 13:541-547.

Martínez-Las Heras R, Amigo-Sánchez JC, Heredia A, Castelló ML, Andrés A (2016). Influence of preharvest treatments to reduce the seasonality of persimmon production on color, texture and antioxidant properties duringstorage. CyTA-Journal of Food 14:333-339.

Noratto G, Martino HS, Simbo S, Byrne D, Mertens-Talcott SU (2015). Consumption of polyphenol-rich peach and plum juice prevents risk factors for obesity-related metabolic disorders and cardiovascular disease in Zucker rats. The Journal of Nutritional Biochemistry 26:633-641.

Oliveira A, Gomes MH, Alexandre E, Almeida D, Pintado M (2014). Impact of $\mathrm{pH}$ on the phytochemical profile of pasteurisation peach puree during storage. Journal of Agricultural and Food Chemistry 62:12075-12081.

Oliveira A, Pintado M, Almeida D (2012). Phytochemical composition and antioxidant activity of peach as affected by pasteurisation and storage duration. LWT - Food Science and Technology 49:202-207.

Petrisor C, Radu GL, Cimpeanu G (2010). Quantification of physicochemical changes during apricot ripening through non-destructive methods. Revistade Chimie 61:345-350.

Sánchez G, Besada C, Badenes ML, Monforte AJ, Granell A (2012). A non-targeted approach unravels the volatile network in peach fruit. PLoSOne 7:e38992.

Singleton VL, Orthofer R, Lamuela-Raventos RM (1999). Analysis of total phenols and other oxidation substrates and antioxidants by means of Folin-Ciocalteu reagent. Methods in Enzymology 299:152-178.

Stojanovic BT, Mitic SS, Stojanovic GS, Mitic MN, Kostic DA, Paunovic DD, Arsic BB (2016). Phenolic profile and antioxidant activity of pulp and peel from peach and nectarine fruits. Notulae Botanicae Horti Agrobotanici 44:175-182.

Sumitani H, Suekane S, Nakatani A, Tatsuka K (1994). Changes in composition of volatile compounds in high pressure treated peach. Journal of Agricultural and Food Chemistry 42:785-790.

Tavarini S, Deg'Innocenti E, Remorini D, Massai R, Guidi L (2008). Preliminary characterization of peach cultivars for their antioxidant capacity. International Journal of Food Science \& Technology 43:810815.

Tomas-Barberan FA, Gil MI, Cremin P, Waterhouse AL, Hess-Pierce B, Kader AA (2001). HPLC-DAD-ESIMS analysis of phenolic compounds in nectarines, peaches, and plums. Journal of Agricultural and Food Chemistry 49:4748-4760.

Vizzotto M, Porter W, Byrne D, Cisneros-Zevallos L (2014). Polyphenols of selected peach and plum genotypes reduce cell viability and inhibit proliferation of breast cancer cells while not affecting normal cells. Food Chemistry 164:363-370.

Wang Y, Yang C, Li S, Yang L, Wang Y, Zhao J, Jiang Q (2009). Volatile characteristics of 50 peaches and nectarines evaluated by HP-SPME with GC-MS. Food Chemistry 11:356-364. 